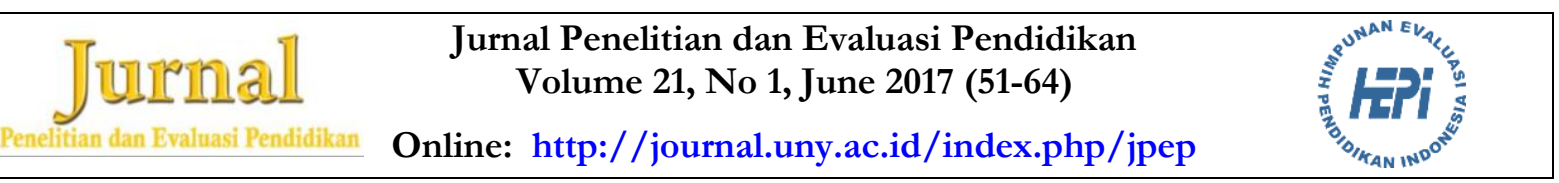

\title{
PENGEMBANGAN TES KEMAMPUAN BERPIKIR KRITIS PADA MATERI OPTIK GEOMETRI UNTUK MAHASISWA FISIKA
}

\author{
Shan Duta Sukma Pradana ${ }^{1} *$ Parno $^{1}$, Supriyono Koes Handayanto ${ }^{1}$ \\ ${ }^{1}$ Universitas Negeri Malang \\ ${ }^{1}$ Jl. Semarang No.5, Sumbersari, Kec. Lowokwaru, Kota Malang, Jawa Timur 65145 \\ * Corresponding Author. Email: shanduta.sp@gmail.com
}

\begin{abstract}
Abstrak
Penelitian ini merupakan jenis penelitian \& pengembangan yang dilakukan dengan tujuan untuk mengembangkan tes kemampuan berpikir kritis. Penelitian ini menggunakan model ADDIE dengan urutan tahapan penganalisisan, perencanaan, pengembangan, pengimplementasian, dan pengevaluasian, tetapi pada penelitian ini hanya dilakukan sampai tahap pengimplementasian. Tes yang dikembangkan dalam penelitian ini terdiri dari lima belas butir soal uraian. Validasi terhadap butir soal tes dilakukan dua kali, yaitu validasi isi dan validasi empiris. Hasil validasi isi menunjukkan bahwa nilai rata-rata butir soal tes sebesar 3,394 berkategori baik, sedangkan hasil validasi empiris menunjukkan bahwa ada sebelas soal berkategori valid dan empat soal berkategori tidak valid. Sebelas soal yang berkategori valid memiliki nilai koefisien reliabilitas Cronbach Alpha sebesar 0,67. Hasil implementasi tes menunjukkan hasil bahwa nilai rata-rata kemampuan berpikir kritis mahasiswa sebesar 27,20 dari 100,00 $\left(S_{D}=11,66\right)$ dengan nilai tertinggi 71,05 dan nilai terendah 2,63. Hal ini menunjukkan bahwa kemampuan berpikir kritis mahasiswa masih kurang.
\end{abstract}

Kata kunci: tes kemampuan bepikir kritis, kemampuan berpikir kritis

\section{DEVELOPING CRITICAL THINKING SKILLS TEST IN GEOMETRICAL OPTIC FOR PHYSICS STUDENT}

\begin{abstract}
The kind of this study is the research and development that aims to develop critical thinking skills test. This study uses ADDIE model that has five steps: analyze, design, develop, implement, and evaluate, but in this study only done until the implementing step. This test consists of fifteen items essay test. Validation of this test performed twice, content validation and empirical validation. Content validation shows that this test have good categorized with average score 3,394, whereas empirical validation shows that there are eleven items that have valid categorized and four items that have invalid categorized. The valid items have reliabity coefficient Alpha Cronbach 0,67. The result of implementing step shows that students have average of critical thinking skill score 27,20 from 100,00 $\left(S_{D}=11,66\right)$ with the higest score 71,05 and the lowest score 2,63. This result shows that students' critical thinking skills are still lacks.
\end{abstract} Keywords: critical thinking skills test, critical thinking skills

Permalink/DOI: http://dx.doi.org/10.21831/pep.v21i1.13139 


\section{Pendahuluan}

Kemampuan berpikir kritis merupakan salah satu tuntutan yang harus dipenuhi pada pembelajaran saat ini. Perhatian pembelajaran terhadap kemampuan berpikir kritis disebabkan oleh pengaruhnya bagi orang dalam mengikuti perkembangan ilmu pengetahuan dan tekonolgi yang saat ini berkembang sangat pesat (Luthvitasari, Putra, Linuwih, 2012). Selain itu, kesuksesan dan profesionalitas seseorang juga sangat dipengaruhi oleh kemampuan berpikir kritis yang dimilikinya Quitadamo, Faiola, Johnson, \& Kurtz, 2008). Penelitian yang dilakukan oleh Frijters, Dam, \& Rijlaarsdam, (2008), menyatakan bahwa jika seseorang memiliki kemampuan berpikir kritis yang kurang, maka orang tersebut akan kesulitan untuk bersaing di dunia global. Pada sisi lain, jika seseorang yang memiliki kemampuan berpikir kritis yang baik, maka orang tersebut dapat ikut serta berperan sebagai konsumen sains (National Research Council, 2012).

Saat ini, banyak penelitian yang mengkaji tentang kemampuan berpikir kritis. Pengkajian tersebut tentu saja memerlukan tes pengukuran agar dapat mengukur kemampuan berpikir kritis dengan tepat. Pengukuran kemampuan berpikir kritis seseorang dapat dilakukan dengan menggunakan tes pilihan ganda berasalan, tes keterampilan (Ennis, 1993; Ennis, 1996), dan tes uraian (Ennis, 1993). Pada penelitian ini dipilih pengembangan tes uraian untuk mengukur kemampuan berpikir kritis mahasiswa fisika.

Jenis penelitian \& pengembangan tes kemampuan berpikir kritis telah pernah dilakukan sebelumnya. Ennis (1993) pernah mengembangkan tes kemampuan berpikir kritis, tetapi bebas materi. Selain itu, penelitian \& pengembangan tes kemampuan berpikir kritis yang terkait materi juga pernah dilakukan, seperti penelitian Kartimi \& Liliasari (2012) yang mengembangkan tes kemampuan berpikir kritis berbentuk pilihan ganda tetapi pada materi termokimia dan Amalia \& Susilaningsih (2014) yang mengembangkan tes kemampuan berpikir kritis berbentuk uraian pada materi asam basa.
Selain itu, penelitian terkait pengembangan alat ukur kemampuan berpikir kritis juga pernah dilakukan oleh Amarila, Habibah, \& Widiyatmoko, (2014) berbentuk tes pilihan ganda, isian singkat, dan uraian pada mata pelajaran IPA tingkat SMP dan Jazuli \& Wardani (2015) berbentuk tes uraian pada mata pelajaran IPA tingkat SMP. Akan tetapi, untuk materi fisika masih jarang dilakukan penelitian \& pengembangan tes kemampuan berpikir kritis.

Tes yang dikembangkan dalam penelitian \& pengembangan ini berupa tes uraian kemampuan berpikir kritis untuk mahasiswa fisika pada materi optik geometri. Pemilihan bentuk tes uraian didasarkan pada karakteristik materi optik geometri yang lebih banyak membuat diagram daripada perhitungan. Selain itu, banyak kesulitan yang dialami dalam mempelajari materi optik geometri, seperti konsep tentang pemantulan dan pembiasan (Aydin, Keleş, \& Haşiloğlu, 2012; Galili \& Hazan, 2000) dan pembentukan bayangan dari peristiwa pemantulan dan pembiasan (Chang et al., 2007; Parker, 2006; Galili \& Hazan, 2000). Tujuan penelitian ini adalah mengembangkan tes kemampuan berpikir kritis untuk mahasiswa fisika pada materi optik geometri dalam mata kuliah Fisika Dasar III. Tujuan lainnya adalah mengetahui validitas dan reliabilitas dari tes yang telah dikembangkan. Selain itu, sebagai tahap implementasi, penelitian ini juga bertujuan untuk mengetahui kemampuan berpikir kritis mahasiswa fisika Univeritas Negeri Malang, khusunya pada materi optik geometri.

\section{Metode Penelitian}

Penelitian ini termasuk jenis penelitian \& pengembangan dengan mengadaptasi langkah penelitian model ADDIE dari Branch (2009). Terdapat lima tahapan dalam model tersebut, yaitu: (a) analyze (penganalisisan), (b) design (perencanaan), (c) develop (pengembangan), (d) implement (pengimplementasian), dan (e) evaluate (pengeveluasian). Pada penelitian ini, dilakukan hanya sampai tahap keempat yaitu pengimplementasian. Total waktu yang diperlukan dalam pene- 
litian ini adalah tujuh bulan (bulan Juni sampai Desember 2016).

Tahap pertama adalah penganalisisan. Pada tahap ini dilakukan telaah terhadap tes pengukuran kemampuan berpikir kritis yang sudah ada. Ennis (1993) telah mengembangkan tes uraian untuk mengukur kemampuan berpikir kritis, tetapi tes uraian tersebut bersifat umum. Selain itu, Kartimi \& Liliasari (2012) juga telah mengembangkan tes kemampuan berpikir kritis tetapi pada materi termokimia, Amalia \& Susilaningsih (2014) pada materi asam basa serta Amarila et al, (2014) dan Jazuli \& Wardani (2015) pada mata pelajaran IPA tingkat SMP. Tes berpikir kritis yang berkaitan dengan materi optik geometri untuk mahasiswa fisika masih belum ada. Oleh karena itu dilakukan pengembangan tes kemampuan berpikir kritis pada materi optik geometri untuk mahasiswa fisika.

Tahap kedua adalah perencanaan. $\mathrm{Pa}$ da tahap ini dilakukan pemilihan patokan dalam pengembangan tes kemampuan berpikir kritis. Patokan yang dipilih adalah lima aspek kemampuan berpikir kritis yang dikememukakan oleh Ennis (1987), yaitu: (a) memberikan penjelasan dasar, (b) membangun keterampilan dasar, (c) menyimpulkan, (d) memberikan penjelasan lanjut, dan (e) strategi dan taktik. Kelima aspek tersebut kemudian menjadi patokan dalam mengembangkan butir soal.

Tahap ketiga adalah pengembangan. Tes kemampuan berpikir kritis dikembangkan dari kelima aspek kemampuan berpikir kritis yang menjadi patokan. Terdapat lima belas butir soal uraian yang dikembangkan dalam penelitian ini. Lima belas soal tersebut mewakili lima aspek kemampuan berpikir kritis. Kelima aspek kemampuan berpikir kritis dan rincian butir soal yang mewakilinya ditunjukkan pada Tabel 1.

Setelah pengembangan tes selesai, tes tersebut kemudian divalidasi. Validasi dilakukan dua kali, yaitu validasi isi dan validasi empiris. Validasi isi dilakukan oleh dua orang dosen Jurusan Fisika FMIPA Universitas Negeri Malang, yang terdiri dari satu dosen ahli materi fisika dan satu dosen ahli pendidikan fisika. Validasi ini meliputi empat aspek, yaitu: (a) kesesuaian butir soal dengan indikator, (b) tingkat kesukaran butir soal (konsep soal), (c) penggunaan bahasa dalam butir soal, dan (d) kebenaran konsep kunci jawaban. Selain itu, validasi isi juga dilakukan untuk mendapatkan saran terhadap butir soal tes dari ahli. Analisis data dari hasil validasi isi dilakukan dengan metode deskripsi rata-rata. Selain itu, butir soal tes juga direvisi berdasarkan saran dari ahli.

Tabel 1. Lima Aspek Kemampuan Berpikir Kritis dan Rincian Butir Soal yang Mewakilinya

\begin{tabular}{clc}
\hline No & \multicolumn{1}{c}{$\begin{array}{c}\text { Aspek Kemampuan Berpikir } \\
\text { Kritis }\end{array}$} & Butir Soal \\
\hline 1 & Memberikan penjelasan dasar & $1,2,3$, dan 4 \\
2 & Membangun keterampilan dasar & 5,6 , dan 7 \\
3 & Menyimpulkan & 8, 9, dan 10 \\
4 & Memberikan penjelasan lanjut & 11 dan 12 \\
5 & Strategi dan taktik & 13,14 , dan 15 \\
\hline
\end{tabular}

Setelah dilakukan tahap revisi, maka dilakukan tahap validasi empiris. Validasi empiris dilakukan terhadap mahasiswa S1 Pendidikan Fisika dan S1 Fisika FMIPA Universitas Negeri Malang angkatan 2015 yang dipilih secara acak sebanyak 68 mahasiswa. Validasi ini digunakan untuk mengetahui validitas dan reliabilitas butir soal. Validitas butir soal dianalisis dengan menggunakan perhitungan koefisien korelasi antara skor butir soal uraian dengan total soal uraian yang dirumuskan (Djaali \& Muljono, 2008, p. 86). Butir soal tes dikatakan valid jika $r_{i t}>r_{\text {tabel }}$. Reliabilitas butir soal dianalisis dengan menggunakan perhitungan koefisien Cronbach Alpha (Djaali \& Muljono, 2008, p. 89).

Tahap keempat adalah pengimplementasian. Pada tahap ini, tes yang sudah diketahui validitas dan reliabilitasnya digunakan untuk mengukur kemampuan berpikir kritis mahasiswa fisika. Jumlah responden adalah 109 mahasiswa fisika Universitas Negeri Malang dengan rincian 87 mahasiswa prodi S1 Pendidikan Fisika dan 22 mahasiswa prodi S1 Fisika. 


\section{Hasil Penelitian dan Pembahasan}

Penelitian \& pengembangan ini diawali dengan menentukan tujuan penelitian, yaitu mengembangkan tes kemampuan berpikir kritis dan mengetahui validitas dan reliabilitas tes tersebut. Setelah itu, dilakukan pemilihan patokan yang digunakan dalam pengembangan butir soal tes. Pada penelitian \& pengembangan ini dipilih patokan yaitu kemampuan bepikir kritis yang dikemukakan oleh Ennis (1987) yang terdiri dari lima kemampuan berpikir kritis, seperti yang telah dijelaskan sebelumnya. Setelah pengembangan selesai, dilakukan validasi isi untuk mengetahui skor rata-rata butir soal dan mendapatkan saran untuk perbaikan butir soal. Penskoran validasi isi menggunakan lembar penilaian dengan rentang nilai 1 sampai 4.

\section{Hasil Validasi Isi}

Validasi isi meliputi empat aspek seperti yang telah dijelaskan sebelumnya. Hasil validasi isi ditunjukkan pada Tabel 2.

\section{Pembahasan Validasi Isi}

Dari data Tabel 2, diketahui bahwa semua butir soal memiliki kriteria valid. Rata-rata nilai butir soal adalah 3,394 yang menunjukkan kategori valid dan layak untuk digunakan. Hal ini juga didukung oleh hasil penelitian oleh Jazuli \& Wardani (2015) yang mengembangkan alat evaluasi dengan nilai rata-rata hasil validasi isi 3,627 dan layak untuk digunakan. Saran dari hasil validasi isi hanya terdapat pada enam butir soal saja, yang terdiri dari dua jenis saran, yaitu perbaikan jawaban dan kesesuaian soal dengan kemampuan berpikir kritis. Saran terhadap butir soal selengkapnya ditunjukkan pada Tabel 3.

Tabel 2. Rekapitulasi Hasil Validasi Isi

\begin{tabular}{ccccccc}
\hline \multicolumn{6}{c}{ Pernyatan } \\
$\begin{array}{c}\text { Butir } \\
\text { soal }\end{array}$ & $\begin{array}{c}\text { Kesesuaian } \\
\text { butir soal } \\
\text { dengan } \\
\text { indikator }\end{array}$ & $\begin{array}{c}\text { Tingkat kesukaran } \\
\text { butir soal sesuai } \\
\text { dengan jenjang } \\
\text { mahasiswa S1 }\end{array}$ & $\begin{array}{c}\text { Butir soal menggunakan } \\
\text { bahasa yang mudah } \\
\text { dimengerti dan tidak } \\
\text { menimbulkan } \\
\text { penafsiran ganda }\end{array}$ & $\begin{array}{c}\text { Kebenaran } \\
\text { konsep kunci } \\
\text { jawaban }\end{array}$ & $\begin{array}{c}\text { Rata- } \\
\text { rata }\end{array}$ & Keterangan \\
\hline 1 & 4 & 2,5 & 3 & 3 & 3,125 & valid \\
2 & 3,5 & 2,5 & 3,5 & 3,5 & 3,25 & valid \\
3 & 3,5 & 3,25 & 4 & 3,25 & 3,5 & valid \\
4 & 3,5 & 3,5 & 4 & 3,5 & 3,625 & valid \\
5 & 3,5 & 3 & 3 & 3,5 & 3,25 & valid \\
6 & 3 & 3 & 3,5 & 3,5 & 3,25 & valid \\
7 & 3 & 3 & 3,5 & 3,5 & 3,25 & valid \\
8 & 3 & 4 & 3,5 & 3,5 & 3,5 & valid \\
9 & 4 & 3,5 & 3,5 & 3,5 & 3,625 & valid \\
10 & 3,5 & 3,5 & 3 & 3,5 & 3,5 & valid \\
11 & 3,5 & 3 & 3,5 & 3,5 & 3,25 & valid \\
12 & 3 & 3 & 3 & 3,5 & 3,25 & valid \\
13 & 3,5 & 4 & 3,5 & 3,25 & 3,475 & valid \\
14 & 3 & 3,5 & 3,5 & 3,5 & 3,375 & valid \\
15 & 3 & 3,5 & 3,417 & 3,5 & 3,375 & valid \\
\hline Rata- & 3,292 & 3,375 & 3,479 & 3,394 & valid \\
rata & & & & & & \\
\hline
\end{tabular}


Tabel 3. Saran dari Hasil Validasi Isi

\begin{tabular}{cl}
\hline Butir soal & \multicolumn{1}{c}{ Saran } \\
\hline 2 dan 13 & $\begin{array}{l}\text { Jawaban disesuaikan } \\
\text { dengan pertanyaan }\end{array}$ \\
$6,12,14$, dan 15 & $\begin{array}{l}\text { Butir soal disesuaikan } \\
\text { dengan indikator butir soal }\end{array}$ \\
\hline
\end{tabular}

Berdasarkan hasil validasi isi, revisi dilakukan terhadap butir soal tes. Contoh revisi terhadap butir soal dapat dilihat pada Gambar 1. Meskipun kelima belas butir soal dinyatakan baik berdasarkan validasi isi, hal ini belum cukup kuat untuk menyimpulkan bahwa butir soal tersebut valid dan reliabel untuk mengukur kemampuan berpikir kritis mahasiswa. Validasi isi tersebut hanya terbatas pada kesesuaian materi dengan kemampuan berpikir kritis. Hasil validasi isi belum bisa menunjukkan bagaimana respon mahasiswa terhadap butir soal tersebut. Oleh karena itu, perlu adanya validasi lanjutan untuk mengetahui tingkat validitas dan reliabilitas butir soal yang telah dikembangkan serta mengetahui respon mahasiswa terhadap butir soal.

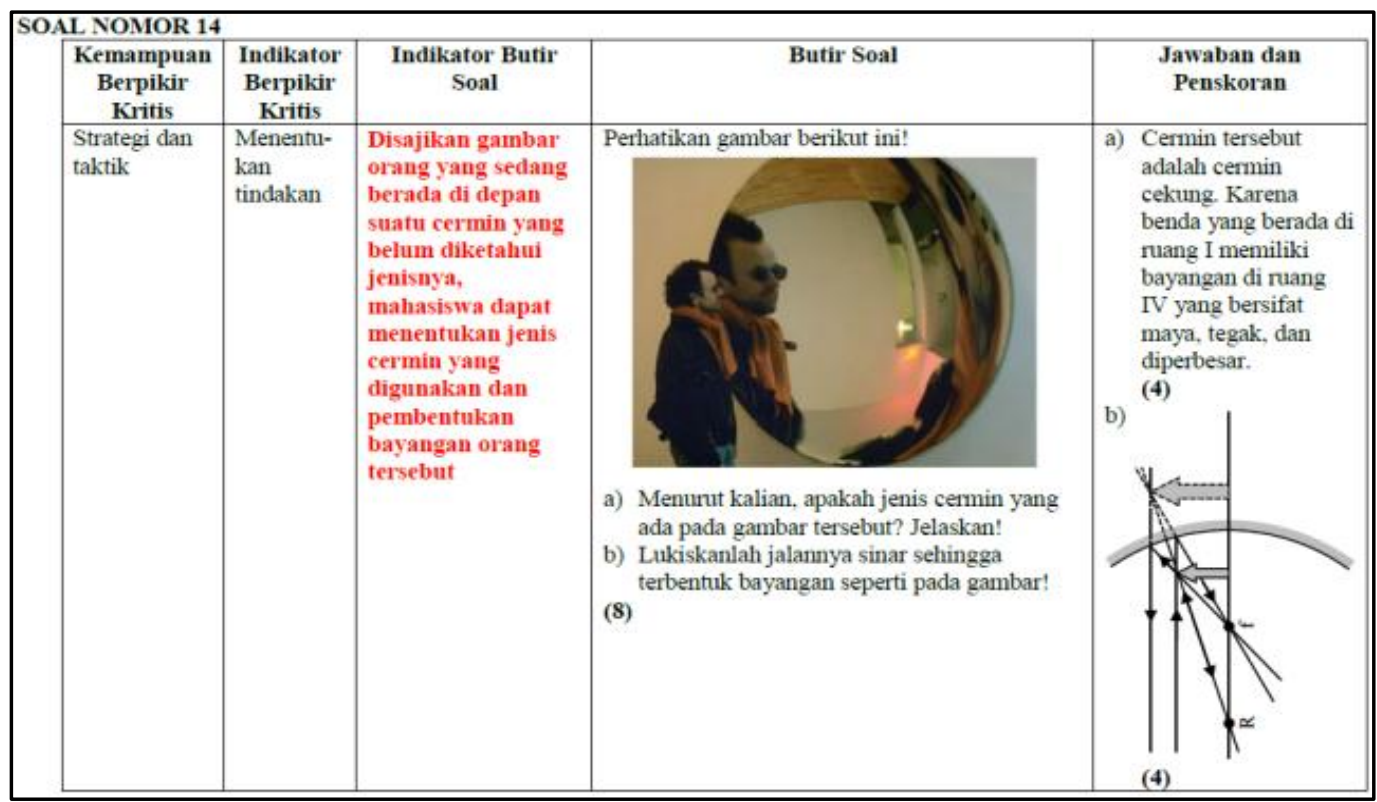

\begin{tabular}{|c|c|c|c|c|}
\hline \multicolumn{5}{|c|}{ REVISI SOAL NOMOR 14} \\
\hline \begin{tabular}{|c} 
Kemampuan \\
Berpikir \\
Kritis
\end{tabular} & $\begin{array}{c}\text { Indikator } \\
\text { Berpikir } \\
\text { Kritis }\end{array}$ & $\begin{array}{c}\text { Indikator Butir } \\
\text { Soal }\end{array}$ & Butir Soal & $\begin{array}{c}\text { Jawaban dan } \\
\text { Penskoran }\end{array}$ \\
\hline $\begin{array}{l}\text { Strategi dan } \\
\text { taktik }\end{array}$ & $\begin{array}{l}\text { Menentu- } \\
\text { kan } \\
\text { tindakan }\end{array}$ & $\begin{array}{l}\text { Disajikan gambar } \\
\text { orang yang sedang } \\
\text { berada di depan } \\
\text { suatu cermin yang } \\
\text { belum diketahui } \\
\text { jenisnya, } \\
\text { mahasiswa dapat } \\
\text { menentukan jenis } \\
\text { cermin yang } \\
\text { digunakan dan } \\
\text { menggambarkan } \\
\text { pembentukan } \\
\text { bayangan orang } \\
\text { tersebut }\end{array}$ & $\begin{array}{l}\text { Perhatikan gambar berikut ini! } \\
\text { a) Menurut kalian, apakah jenis cermin yang } \\
\text { ada pada gambar tersebut? Jelaskan! } \\
\text { b) Lukiskanlah jalannya sinar sehingga } \\
\text { terbentuk bayangan seperti pada gambar! } \\
\text { (8) }\end{array}$ & $\begin{array}{l}\text { a) Cermin tersebut } \\
\text { adalah cermin } \\
\text { cekung. Karena } \\
\text { benda yang berada di } \\
\text { ruang I memiliki } \\
\text { bayangan di ruang } \\
\text { TV yang bersifat } \\
\text { maya, tegak, dan } \\
\text { diperbesar. }\end{array}$ \\
\hline
\end{tabular}

Gambar 1. Contoh Revisi dari Hasil Validasi Isi 


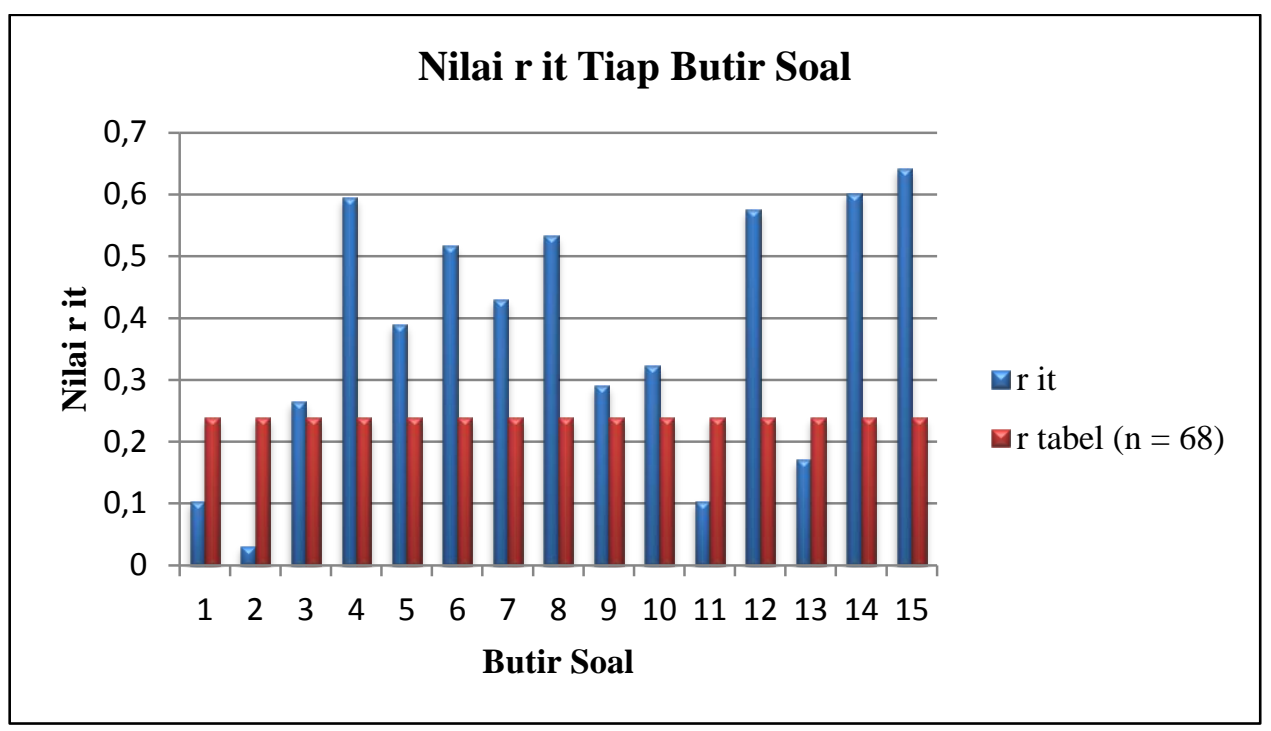

Gambar 2. Nilai Validitas Tiap Butir Soal

Hasil Validasi Empiris

Validasi empiris dilakukan dengan subjek mahasiswa S1 Pendidikan Fisika dan S1 Fisika FMIPA Universitas Negeri Malang angkatan 2015 yang dipilih secara acak sebanyak 68 mahasiswa. Mahasiswa diberi waktu 100 menit untuk mengerjakan butir soal tes secara mandiri. Setelah mahasiswa mengerjakan tes, jawaban mahasiswa kemudian dikoreksi dan dianalisis. Hasil analisisnya ditunjukkan pada Tabel 4. Gambar 2 menunjukkan perbandingan nilai $r_{i t}$ dan $r_{\text {tabel }}$ untuk setiap butir soal.

Tabel 4. Hasil Analisis Validasi Empiris

\begin{tabular}{cccc}
\hline Butir soal & $\mathrm{r}_{\text {it }}$ & $\mathrm{r}_{\text {tabel }}(\mathrm{n}=68)$ & Keterangan \\
\hline 1 & 0,1043 & & Tidak valid \\
2 & 0,0312 & & Tidak valid \\
3 & 0,2648 & & Valid \\
4 & 0,5949 & & Valid \\
5 & 0,3899 & & Valid \\
6 & 0,5167 & & Valid \\
7 & 0,4295 & & Valid \\
8 & 0,5334 & 0,2387 & Valid \\
9 & 0,2899 & & Valid \\
10 & 0,3224 & & Valid \\
11 & 0,1035 & & Tidak valid \\
12 & 0,5756 & & Valid \\
13 & 0,1712 & & Tidak valid \\
14 & 0,6025 & & Valid \\
15 & 0,6422 & & Valid \\
\hline
\end{tabular}

Pembahasan Validasi Empiris

Berdasarkan Tabel 4 dan Gambar 2, diketahui bahwa terdapat empat butir soal yang tidak valid, yaitu butir soal nomor 1, 2, 11, dan 13. Hal ini berarti bahwa keempat butir soal ini tidak dapat mengukur kemampuan berpikir kritis yang dimiliki oleh mahasiswa. Berdasarkan analisis terhadap jawaban mahasiswa, diketahui bahwa butir soal nomor 2 terlalu mudah, sehingga hampir semua mahasiswa dapat menjawabnya dengan benar. Pada sisi lain, butir soal nomor 1, 11, dan 13 terlalu sulit, sehingga hampir semua mahasiswa menjawabnya dengan salah.

Butir soal nomor 1 ditunjukkan pada Gambar 3. Hasil validasi empiris menunjukkan bahwa 57,35\% mahasiswa tidak dapat menjawab dengan benar soal nomor 1. Banyak mahasiswa yang menjawab bahwa kejadian tersebut rasional. Seperti yang diketahui bahwa cermin cekung hanya memiliki satu titik fokus saja. Jika ingin membakar seluruh armada dalam waktu yang bersamaan tidak mungkin dapat dilakukan. Hal ini analogi dengan prinsip kerja kompor surya. Banyak mahasiswa yang menjawab salah pada soal ini, tetapi dapat menjawab dengan benar pada soal yang lain. Hal inilah yang menyebabkan soal nomor 1 tidak valid. 
Archimedes diceritakan telah membakar seluruh armada Roma di pelabuhan Syracuse dengan memfokuskan berkas sinar matahari dengan cermin cekung yang besar. Menurn pendapat Anda, apakah cerita tersebut rasional? Jelaskan!

\section{Gambar 3. Soal Nomor 1}

Butir soal nomor 2 ditunjukkan pada Gambar 4. Hasil validasi empiris menunjukkan bahwa 58,82\% mahasiswa dapat menjawab dengan cukup benar soal nomor 2 . Meskipun cukup benar, tetapi jawaban mahasiswa tersebut hampir sama sehingga mendapatkan nilai yang sama pada soal nomor 2. Selain itu, mahasiswa yang pada nomor lain tidak dapat menjawab dengan benar, dapat dengan mudah menjawab soal nomor 2. Hal ini menyebabkan butir soal nomor 2 tidak valid. Banyak mahasiswa yang menjawab bahwa keadaan silau yang dialami Ibu Rahma disebabkan karena pantulan dari lampu kendaraan lain oleh aspal yang basah sehingga mengenai mata Ibu Rahma.

Ibu Rahma sedang pulang bekerja dari kantor saat malam hari. Saat beliau pulang. ternyata cuaca sedang hujan. Hal ini menyebabkan Ibu Rahma tidak berani memacu mobilnya dengan cepat. Selain karena licin, Ibu Rahma mengatakan bahwa saat itu, aspa jalan telihat menyilaukan mata. Menurut Anda, bagaimanakah penjelasan dari kejadian yang dialami Ibu Rahma? Jelaskan!

\section{Gambar 4. Soal Nomor 2}

Butir soal nomor 11 ditunjukkan pada Gambar 5. Hasil validasi empiris menunjukkan bahwa $94,12 \%$ mahasiswa tidak dapat menjawab dengan benar soal nomor 11 . Meskipun sebenarnya mahasiswa mengetahui macam-macam sinar istimewa, tetapi mereka tidak mengetahui syarat penggunaan sinar istimewa. Sinar-sinar istimewa dapat digunakan untuk melukiskan bayangan jika sinar tersebut berada di dekat sumbu utama. Karena hampir semua mahasiswa tidak dapat menjawab dengan benar soal tesebut, maka butir soal nomor 11 menjadi tidak valid.

apan penggunaan sinar-sinar istimewa dapat dilakukan saat menggambarkan jalannya sinar pada pemantulan cermin cekung? Jelaskan jawabanmu!

\section{Gambar 5. Soal Nomor 11}

Butir soal nomor 13 ditunjukkan pada Gambar 6. Hasil validasi empiris menunjukkan bahwa $75,00 \%$ mahasiswa tidak dapat menjawab dengan benar soal nomor 13 . Sebagian besar responden menjawab bahwa cermin cembung paling efektif diletakkan di posisi D. Padahal jawaban tersebut adalah jawaban yang kurang benar. Seharusnya posisi cermin cembung yang paling efektif adalah pada posisi B dan E. Selain disebabkan karena banyak mahasiswa yang tidak dapatmenjawab dengan benar, petunjuk arah hadap cermin cembung juga tidak dijelaskan pada soal. Hal inilah yang menyebabkan butir soal nomor 13 tidak valid.

Kesebelas soal yang dinyatakan valid telah mewakili lima aspek kemampuan berpikir kritis yang dijadikan patokan dalam penyusunan butir soal tes kemampuan berpikir kritis. Aspek pertama terdapat pada butir soal nomor 3 dan 4. Aspek kedua terdapat pada soal nomor 5, 6, dan 7. Aspek ketiga terdapat pada butir soal nomor 8, 9, dan 10 . Aspek keempat terdapat pada butir soal nomor 12. Aspek kelima terdapat pada butir soal nomor 14 dan 15 .

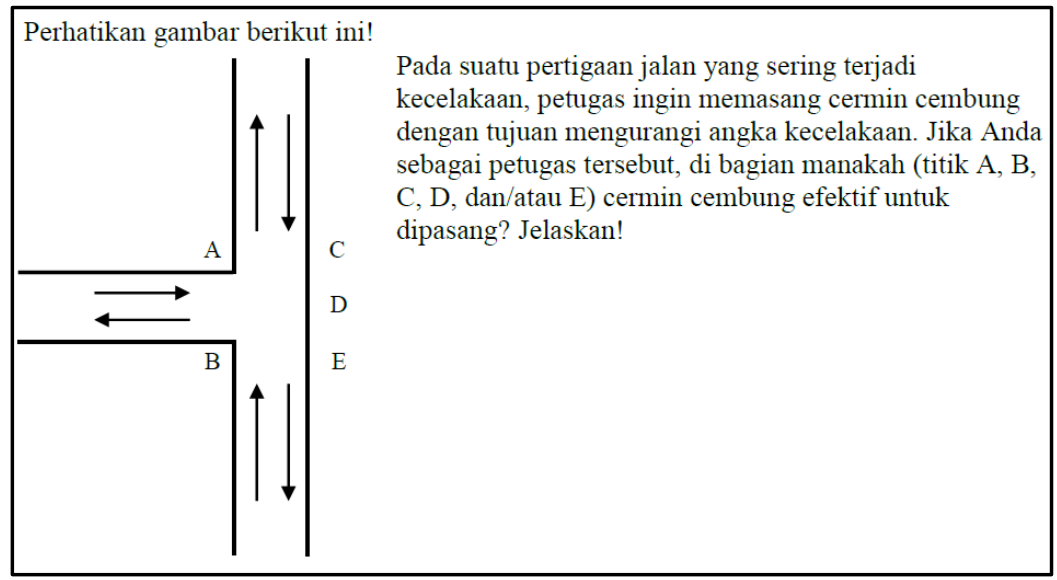

Gambar 6. Soal Nomor 13 
Setelah diketahui ada sebelas butir soal yang dinyatakan valid, maka kesebelas butir soal tersebut diuji reliabilitasnya untuk mengetahui tingkat keajegan saat digunakan untuk mengukur kemampuan berpikir kritis mahasiswa. Berdasarkan hasil perhitungan, didapatkan nilai koefisien reliabilitas Cronbach Alpha adalah $r_{i i}=0,67$ yang berarti butir soal memiliki tingkat keajegan yang tinggi (Arikunto, 2012; Ghozali, 2007), sehingga dapat digunakan untuk mengukur kemampuan berpikir kritis mahasiswa. Validitas dan reliabilitas butir soal yang baik dipengaruhi oleh beberapa faktor. Menurut Istiyono, Mardapi, \& Suparno (2014) terdapat empat faktor yang menyebabkan validitas dan reliabilitas baik, yaitu (a) butir soal dikembangkan sesuai dengan prosedur pengembangan, (b) butir soal dikembangkan dari acuan yang tepat, (c) butir soal melalui tahap validasi isi, dan (d) butir soal diuji empiris dengan responden yang mengerjakan dengan sungguh-sungguh dan diawasi dengan ketat. Semua faktor tersebut telah dilakukan dalam penelitian ini, sehingga buir soal dalam penelitian ini memiliki validitas dan reliabiltas yang baik.

Tes yang telah diketahui validitas dan reliabilitasnya kemudian digunakan untuk mengukur kemampuan berpikir kritis mahasiswa fisika Universitas Negeri Malang. Hal ini bertujuan untuk mengetahui bagaimana deskripsi kemampuan berpikir kritis mahasiswa fisika.

\section{Hasil Implementasi Soal Tes}

Implementasi butir soal dilakukan dengan subjek 109 mahasiswa fisika Universitas Negeri Malang dengan rincian $87 \mathrm{ma-}$ hasiswa prodi S1 Pendidikan Fisika dan 22 mahasiswa prodi S1 Fisika. Hasilnya dapat dilihat pada Tabel 5 .

Berdasarkan hasil pada Tabel 5, diketahui bahwa kemampuan berpikir kritis mahasiswa fisika Universitas Negeri Malang masih kurang. Hal ini dibuktikan dengan nilai rata-rata kemampuan berpikir kritis mahasiswa hanya pada nilai 27,20. Hasil ini sama dengan hasil penelitian Putra \& Sudarti (2015) yang menunjukkan bahwa rata-rata kemampuan berpikir kritis mahasiswa pada nilai 37 dan hasil penelitian Pradana, Parno, \& Handayanto (2016) yang menunjukkan bahwa rata-rata kemampuan berpikir kritis mahasiswa fisika adalah 24,29. Sejalan dengan penelitian tersebut, penelitian lain juga mendapatkan hasil nilai rata-rata kemampuan berpikir kritis calon guru fisika adalah 30 (Gunawan \& Liliasari, 2012). Ini semakin memperkuat bahwa kemampuan berpikir kritis pebelajar, termasuk mahasiswa di Indonesia masih kurang. Hal inilah yang menyebabkan mahasiswa Indonesia kurang bisa bersaing dalam dunia internasional (Frijters et al, 2008).

Tabel 5. Hasil Penggunaan Tes Berpikir Kritis

\begin{tabular}{lc}
\hline \multicolumn{1}{c}{ Aspek } & Nilai \\
\hline Jumlah responden & 109 \\
Nilai rata-rata & 27,20 \\
Standar deviasi & 11,66 \\
Nilai tertinggi & 71,05 \\
Nilai terendah & 2,63 \\
Nilai maksimum & 100,00 \\
\hline
\end{tabular}

Pembahasan Impelemtasi Soal Tes

Aspek pertama: Memberikan penjelasan dasar

Aspek pertama diwakili oleh dua soal, yaitu soal nomor 3 dan 4. Rangkuman hasil penelitian untuk aspek pertama disajikan pada Tabel 6.

Tabel 6. Rangkuman Hasil Aspek Pertama

\begin{tabular}{lc}
\hline \multicolumn{1}{c}{ Aspek } & Nilai \\
\hline Nilai rata-rata & 27,64 \\
Nilai tertinggi & 100,00 \\
Nilai terendah & 0,00 \\
Nilai maksimum & 100,00 \\
\hline
\end{tabular}

Hal ini menunjukkan bahwa kemampuan berpikir kritis mahasiswa dalam memberikan penjelasan dasar masih kurang. Hal ini berbeda dengan hasil penelitian Dwijananti \& Yulianti (2010) yang menunjukkan bahwa pada kemampuan berpikir kritis dalam memberikan penjelasan dasar memiliki nilai rata-rata yang tinggi, yaitu 79,83. Mahasiswa masih belum dapat menganalisis pertanyaan dalam soal yang disaji- 
kan. Selain itu, mahasiswa juga masih kesulitan dalam memahami maksud pertanyan dalam soal. Misalnya soal nomor 4 yang ditunjukkan pada Gambar 7.

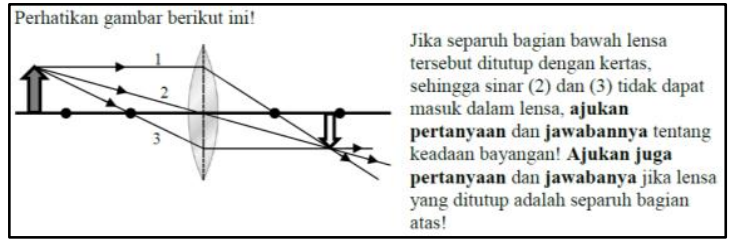

Gambar 7. Soal Nomor 4

Pada soal tersebut terdapat perintah untuk mengajukan pertanyaan dan jawabannya yang disampaikan dengan jelas, tetapi banyak mahasiswa yang tidak memahami maksud soal tersebut. Ada mahasiswa yang hanya memberikan jawaban saja atau pertanyaan saja. Selain itu, tidak sedikit juga mahasiswa yang mengajukan pertanyaan dan jawaban tetapi tidak sesuai dengan ketentuan pada soal.

Penyebab hal tersebut dapat terjadi karena soal dengan tipe seperti soal nomor 4 masih jarang dihadapi oleh mahasiswa. Mahasiswa sering mengahadapi soal yang tidak diminta untuk mengajukan pertanyaan dan jawaban secara bersamaan. Selain jarang menghadapi soal dengan tipe tersebut, terdapat faktor lain yang mempengaruhi mahasiswa tidak dapat menjawab dengan baik soal nomor 3 dan 4, salah satunya adalah pemahaman terhadap materi optik geometri. Mahasiswa masih belum dapat menjelaskan dengan baik tentang peristiwa pembiasan (Aydin et al, 2012; Galili \& Hazan, 2000) dan pembentukan bayangan pada lensa tipis (Chang et al., 2007; Parker, 2006; Galili \& Hazan, 2000).

\section{Aspek Kedua: Membangun Keterampilan Dasar}

Tabel 7. Rangkuman Hasil Aspek Kedua

\begin{tabular}{lc}
\hline \multicolumn{1}{c}{ Aspek } & Nilai \\
\hline Nilai rata-rata & 25,33 \\
Nilai tertinggi & 94,44 \\
Nilai terendah & 0,00 \\
Nilai maksimum & 100,00 \\
\hline
\end{tabular}

Aspek kedua diwakili oleh tiga soal, yaitu soal nomor 5, 6, dan 7. Rangkuman hasil penelitian untuk aspek kedua disajikan pada Tabel 7.

Hasil tersebut menunjukkan bahwa kemampuan berpikir kritis mahasiswa dalam membangun keterampilan dasar masih kurang. Hal ini juga berbeda dengan hasil penelitian Wahyuni (2015) yang menunjukkan bahwa pada kemampuan berpikir kritis dalam membangun keterampilan dasar memiliki nilai rata-rata yang cukup tinggi, yaitu 67,11. Mahasiswa masih kesulitan saat diminta untuk mengilustrasikan suatu keadaan. Selain itu, mahasiswa juga masih belum bisa memberikan penjelasan dengan menggunakan gambar terkait dengan pengamatan terhadap suatu permasalah jika ditinjau dari sudut pandang yang berbeda. Sebagai contoh adalah pertanyaan pada soal nomor 5 yang disajikan dalam Gambar 8.

Pada soal tersebut mahasiswa tidak diminta untuk menghitung jarak bayangan dari ketiga gambar, tetapi mahasiswa diminta untuk melukiskan jalannya sinar hingga terbentuk bayangan dari ketiga gambar tersebut. Hasilnya adalah sebagian besar mahasiswa tidak dapat melukiskan jalannya sinar hingga terbentuknya bayangan. Hal ini jelas menunjukkan bahwa kemampuan mahasiswa untuk mengilustrasikan suatu kasus masih kurang. Hal ini juga diperkuat dengan tanggapan mahasiswa saat mengerjakan soal. Mahasiswa mengatakan bahwa mereka merasa kesulitan dan tidak senang jika harus menggambarkan ilustrasi dari soal tes yang diberikan.

Penyebab mahasiswa kesulitan untuk mengilustrasikan adalah kurangnya latihan yang diberikan kepada mahasiswa dalam pembelajaran, terutama fisika. Mahasiswa fisika cenderung langsung dapat menyelesaikan permasalahan jika jelas hal diketahui dan rumus yang digunakan. Selain itu, faktor pemahaman materi juga tidak dapat terlepas dalam mempengaruhi kemampuan yang dimiliki mahasiswa. Pada kemampuan berpikir kritis 2 ini, hasil menunjukkan bahwa mahasiswa masih kesulitan untuk menggambarkan bayangan (Chang et al., 2007; Parker, 2006; Galili \& Hazan, 2000) dari peristiwa pembiasan dan pemantulan cahaya (Aydin et al, 2012; Galili \& Hazan, 2000).

Pengembangan Tes Kemampuan Berpikir Kritis ... - 


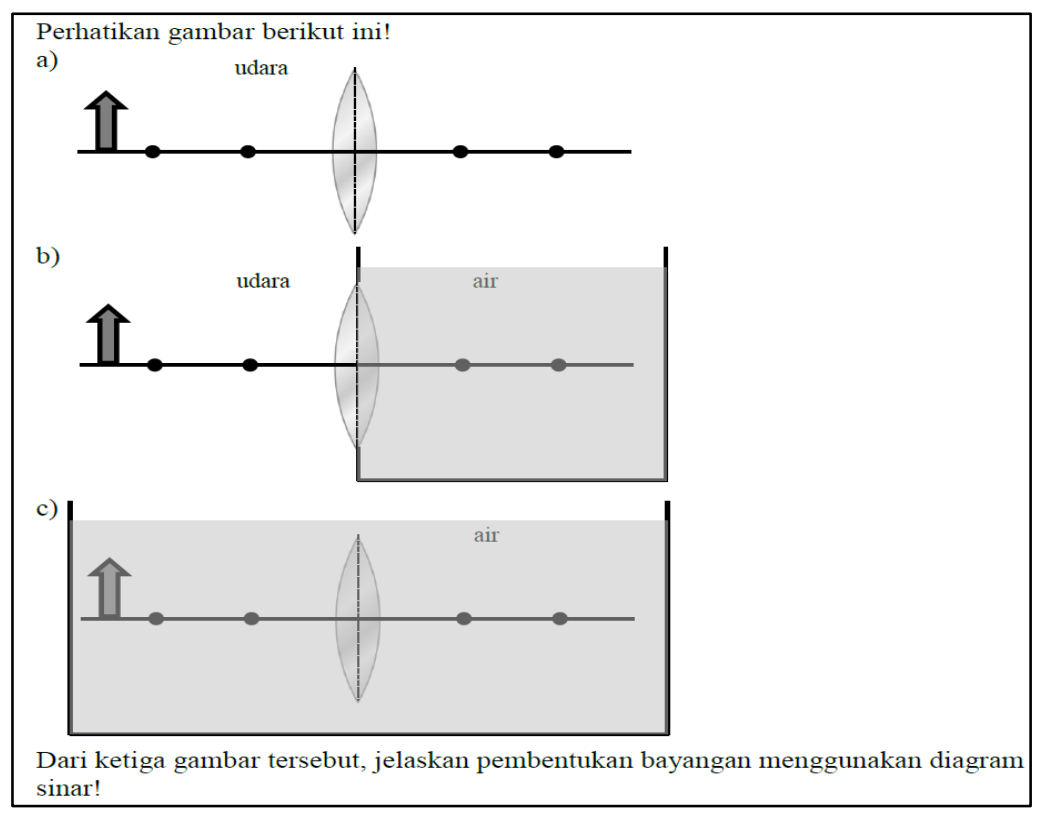

Gambar 8. Soal Nomor 5

\section{Aspek ketiga: Menyimpulkan}

Aspek ketiga diwakili oleh tiga soal, yaitu soal nomor 8, 9, dan 10. Rangkuman hasil penelitian untuk aspek ketiga disajikan pada Tabel 8.

Tabel 8. Rangkuman Hasil Aspek Ketiga

\begin{tabular}{lc}
\hline \multicolumn{1}{c}{ Aspek } & Nilai \\
\hline Nilai rata-rata & 12,44 \\
Nilai tertinggi & 86,67 \\
Nilai terendah & 0,00 \\
Nilai maksimum & 100,00 \\
\hline
\end{tabular}

Hasil tersebut menunjukkan bahwa kemampuan berpikir kritis mahasiswa dalam menyimpulkan masih kurang. Hal ini berbeda dengan hasil penelitian Dwijananti \& Yulianti (2010) yang menunjukkan bahwa pada kemampuan berpikir kritis dalam menyimpulkan memiliki nilai rata-rata yang cukup tinggi, yaitu 68,32. Sebagai contoh adalah soal nomor 9 yang ditunjukkan pada Gambar 9.

Pada soal tersebut mahasiswa diminta untuk menentukan letak bayangan saat pengamatan dilakukan oleh ikan. Mahasiswa berpendapat bahwa soal tersebut adalah soal yang aneh karena mereka masih belum ter- biasa mendapatkan soal yang memerlukan analisis geometri. Soal ini merupakan soal yang tidak memerlukan hitungan, tetapi kemampuan dalam memberikan kesimpulan pengamatan yang dilakukan dari dua sudut pandang berbeda.

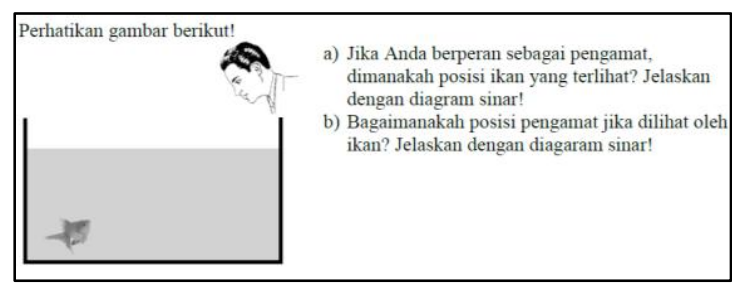

Gambar 9. Soal Nomor 9

Penyebab mahasiswa kesulitan dalam memberikan kesimpulan adalah selain pembelajaran yang diberikan masih jarang mengajak mahasiswa untuk menyimpulkan, pemahaman materi juga memepengaruhi kemampuan mahasiswa. Pada kemampuan berpikir kritis 3, mahasiswa masih kesulitan dalam hal perambatan cahaya (Chu \& Treagust, 2014; Aydin et al, 2012) dan penentuan letak bayangan (Chang et al., 2007; Parker, 2006; Galili \& Hazan, 2000).

\section{Aspek keempat: Memberikan penjelasan lanjut}

Aspek keempat diwakili oleh satu soal, yaitu soal nomor 12. Rangkuman hasil 
penelitian untuk aspek keempat disajikan pada Tabel 9.

Tabel 9. Rangkuman Hasil Aspek Keempat

\begin{tabular}{lc}
\hline \multicolumn{1}{c}{ Aspek } & Nilai \\
\hline Nilai rata-rata & 51,76 \\
Nilai tertinggi & 100,00 \\
Nilai terendah & 0,00 \\
Nilai maksimum & 100,00 \\
\hline
\end{tabular}

Hasil ini merupakan nilai rata-rata tertinggi dalam penelitian ini. Hal ini sama dengan hasil penelitian Wahyuni (2015) yang menunjukkan bahwa pada kemampuan berpikir kritis dalam memberikan penjelasa lanjut memiliki nilai rata-rata yang tertinggi, yaitu 79,92. Pada soal nomor 12 ini mahasiswa diminta untuk menjelaskan benar atau tidaknya gambar yang disajikan. Gambar tersebut terdiri dari 6 gambar pembiasan cahaya pada dua medium yang berbeda. Mahasiswa diminta untuk menentukan benar atau tidaknya gambar tersebut serta dilengkapi dengan alasannya.

Nilai rata-rata tertinggi ini disebabkan karena mahasiswa dapat menentukan jawaban yang tepat dari soal tersebut. Meskipun demikian, masih banyak mahasiswa yang kurang dapat memberikan penjelasan lanjut dari jawaban mereka. Hal ini menyebabkan kemampuan memberikan penjelasan lanjut masih pada diri mahasiswa masih perlu dikembangkan lagi. Selain itu, bukti bahwa kemampuan memberikan penjelasan lanjut mahasiswa masih kurang adalah pernyataan mahasiswa saat mengerjakan soal. Mereka mengatakan bagaimana jika jawaban mereka tidak perlu diberikan alasan lebih lanjut. Selain itu masalah ini juga dipenagruhi oleh pemahaman materi yang kurang dari mahasiswa, terutama pada materi pembiasan cahaya (Aydin et al, 2012; Galili \& Hazan, 2000) yang menjadi materi dari soal nomor 12 ini.

\section{Aspek kelima: Strategi dan taktik}

Aspek kelima diwakili oleh dua soal, yaitu soal nomor 14, dan 15. Rangkuman hasil penelitian untuk aspek kelima disajikan pada Tabel 10.

Tabel 10. Rangkuman Hasil Aspek Kelima

\begin{tabular}{lc}
\hline \multicolumn{1}{c}{ Aspek } & Nilai \\
\hline Nilai rata-rata & 25,87 \\
Nilai tertinggi & 100,00 \\
Nilai terendah & 0,00 \\
Nilai maksimum & 100,00 \\
\hline
\end{tabular}

Berdasarkan hasil pada Tabel 10, diketahui bahwa kemampuan mahasiswa dalam strategi dan taktik masih kurang. Hal ini sama dengan hasil penelitian Yuliati, Yulianti, \& Khanafiyah, (2011) yang menunjukkan bahwa pada kemampuan berpikir kritis dalam strategi dan taktik memiliki nilai rata-rata yang rendah, yaitu 36,27. Mahasiswa masih kesulitan menentukan tindakan untuk menyelesaikan soal. Sebagai contohnya adalah soal nomor 15 yang ditunjukkan pada Gambar 10.

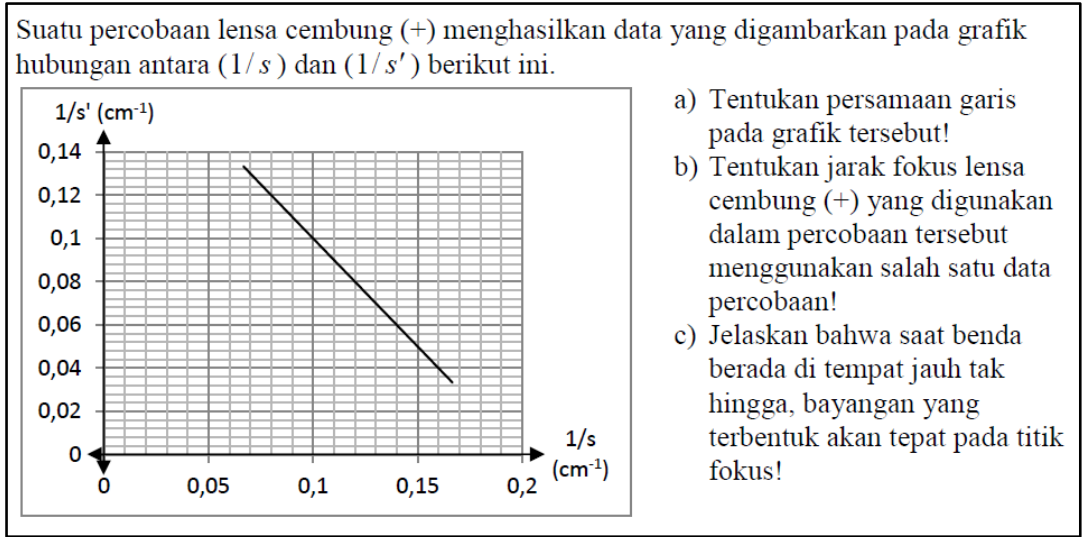

Gambar 10. Gambar 10. Soal Nomor 15 
Soal tersebut menyajikan grafik percobaan yang telah dilakukan. Soal tersebut memerlukan hitungan, tetapi tidaklah hitungan yang rumit. Akan tetapi banyak mahasiswa yang kesulitan untuk menyelesaikannya. Mereka kesulitan untuk menentukan persamaan garis, titik fokus lensa yang digunakan, serta menjelaskan dengan hitungan bayangan benda di jauh tak hingga akan tepat di titik fokus.

Faktor penyebab kesulitan mahasiswa adalah selain jarang diberikan permasalahan tersebut, mahasiswa juga kurang memahami maksud dari grafik. Tidak hanya pada meteri optik geometri saja, pada materi lain pun mahasiswa mengalami kesulitan saat diminta untuk membaca atau membuat grafik atau diagaram. Pembelajaran yang diberikan hendaknya melatih kemampuan mahasiswa dalam menyelesaikan permasalahan seperti pada soal nomor 15. Selain itu, mahasiswa juga harus dilatih untuk mengaitkan kejadian kehidupan nyata dengan ilmu pengetahuan yang mereka pelajari. Hal ini bertujuan agar mahasiswa dapat menganalisis dan menentukan suatu tindakan jika menghadapi permasalah di kehidupan nyata dengan menggunakan ilmu-ilmu yang telah mereka pelajari.

\section{Simpulan}

Berdasarkan hasil penelitian dan analisis data, diketahui bahwa, dari lima belas butir soal yang telah dikembangkan, terdapat sebelas soal yang memiliki kategori valid $\left(r_{i t}>r_{\text {tabel }}\right)$. Kesebelas soal yang dinyatakan valid memiliki tingkat reliabiltas Cronbach Alpha yaitu $r_{i i}=0,67$. Hal ini menunjukkan bahwa kesebelas butir soal tersebut memiliki reliabilitas tinggi, sehingga dapat digunakan untuk mengukur kemampuan berpikir kritis mahasiswa secara valid dan reliabel. Selain itu, kesebelas butir soal tes tersebut telah mewakili kelima kemampuan berpikir kritis yang digunakan sebagai patokan penyusunan tes kemampuan berpikir kritis.

Tes yang telah dinyatakan valid dan reliabel kemudian digunakan untuk mengukur kemampuan berpikir kritis. Jumlah res- pondennya adalah 109 mahasiswa fisika Universitas Negeri Malang dengan rincian 87 mahasiswa prodi S1 Pendidikan Fisika dan 22 mahasiswa prodi S1 Fisika. Hasilnya adalah nilai rata-rata kemampuan berpikir kritis yang dicapai mahasiswa adalah 27,20. Nilai tertinggi yang dicapai mahasiswa adalah 71,05 dan nilai terendahnya adalah 2,63 $\left(S_{D}=11,66\right)$. Hal ini menunjukkan bahwa kemampuan berpikir kritis mahasiswa masih kurang.

\section{Daftar Pustaka}

Amalia, N. F., \& Susilaningsih, E. (2014). Pengembangan Instrumen Penilaian Keterampilan Berpikir Kritis Siswa SMA pada Materi Asam Basa. Jurnal Inovasi Pendidikan Kimia, Vol. 8, No. 2, pp. 1380-1389.

Amarila, R. S, Habibah, N. A., \& Widiyatmoko, A. (2014). Pengembangan alat evaluasi kemampuan berpikir kritis siswa pada pembelajaran ipa terpadu model webbed tema lingkungan. Unnes Science Education Journal, 3(2). doi:10.15294/usej.v3i2.3449

Arikunto, S. (2012). Dasar-dasar evaluasi pendidikan. Jakarta: Bumi Aksara.

Aydin, S., Keleş, P. U., \& Haşiloğlu, M. A. (2012). Establishment for Misconceptions that Science Teacher Candidates have about Geometric Optics. The Online Journal of New Horizon in Education, Vol. 2, No. 3, pp. 7-15.

Branch, R. M. (2009). Instructional Design: The ADDIE Approach. New York: Springer New York.

Chang, H., Chen, J., Guo, C., Chen, C., Chang, C., Lin, S., ... Tseng, Y. (2007). Investigating primary and secondary students' learning of physics concepts in Taiwan. International Journal of Science Education, 29(4), 465-482. https://doi.org/10.1080/09500690601 073210 
Chu, H.-E., \& Treagust, D. F. (2014). Secondary Students' Stable and Unstable Optics Conceptions Using Contextualized Questions. Journal of Science Education and Technology, 23(2), 238-251.

https://doi.org/10.1007/s10956-0139472-6

Djaali \& Muljono, P. (2008). Pengukuran dalam bidang pendidikan. Jakarta: Grasindo.

Dwijananti, P. \& Yulianti, D.. (2010). Pengembangan kemampuan berpikir kritis mahasiswa melalui pembelajaran problem based instruction pada mata kulkiah fisika lingkungan. Jurnal Pendidikan Fisika Indonesia, Vol. 6, pp. 108-114.

Ennis, R. H. (1987). A taxonomy of critical thinking dispositions and abilities, in J. B. Baron \& R. S. Sternberg (Eds.), Teaching thinking skills: Theory and practice. New York: W. H. Freeman.

Ennis, R. H. (1993). Critical thinking assessment. Theory Into Practice, Vol. 32, No. 3, pp. 179-186.

Ennis, R. H. (1996). Critical thinking dispositions: their nature and assessability. Informal Logic, Vol. 18, No. 2 \& 3, pp. 165-182.

Frijters, S., Dam, G., \& Rijlaarsdam, G. (2008). Effects of dialogic on valueloaded critical thinking. Learning and Instruction (Vol. 18). https://doi.org/10.1016/j.learninstruc .2006.11.001

Galili, I., \& Hazan, A. (2000). Learners' knowledge in optics: interpretation, structure and analysis. International Journal of Science Education, Vol. 22, No. 1, pp. 57-88.

Ghozali, I. (2007). Aplikasi multivariate dengan program SPSS. Semarang: Badan Penerbit Universitas Diponegoro.

Gunawan \& Liliasari. (2012). Model virtual laboratory fisika modern untuk meningkatkan disposisi berpikir kritis calon guru. Cakrawala Pendidikan, Vol. 2, pp. 185-199.

Istiyono, E., Mardapi, D., \& Suparno. (2014). Pengembangan tes kemampuan berpikir tingkat tinggi Fisika (PysTHOTS) peserta didik SMA. Jurnal Penelitian dan Evaluasi Pendidikan, Vol. 18, No. 1, pp. 1-12.

Jazuli, M \& Wardani, S. (2015).

Pengembangan Alat Evaluasi IPA Terpadu Topik Perubahan Materi Berbasis Kontekstual untuk Mengukur Kemampuan Berpikir Kritis Siswa. Unnes Science Education Journal, Vol. 4, No. 2, pp. 912-918.

Kartimi \& Liliasari. (2012). Pengembangan Alat Ukur Berpikir Kritis pada Konsep Termokimia untuk Siswa SMA Peringkat Atas dan Menengah. Jurnal Pendidikan IP A Indonesia, Vol. 1, No. 2, pp. 21-26.

Luthvitasari, N, Putra, N. M. D., \& Linuwih, S. (2012). Implementasi pembelajaran fisika berbasis proyek terhadap keterampilan berpikir kritis, berpikir kreatif, dan kemahiran generik sains. Journal of Innovative Science Education, Vol. 1, No. 2, pp. 92-97.

National Research Council. (2012). A Framework for K-12 Science Education. Washington, DC: The National Academies Press.

Parker, J. (2006). Exploring the Impact of Varying Degrees of Cognitive Conflict in the Generation of both Subject and Pedagogical Knowledge as Primary Trainee Teachers Learn about Shadow Formation. International Journal of Science Education. Vol. 28, No. 13, pp. 15451577.

Pradana, S. D. S., Parno, \& Handayanto, S. K. (2016). Kemampuan Berpikir Kritis Mabasiswa Tabun Pertama Jurusan Fisika Universitas Negeri Malang. Makalah disajikan dalam Seminar Nasional Pendidikan IPA. Pascasarjana 
Universitas Negeri Malang. Malang, 8 Oktober 2016.

Putra, P. D. A. \& Sudarti. (2015). Pengembangan Sistem E-Learning untuk Meningkatkan Keterampilan Berpikir Kritis Mahasiswa. Jurnal Fisika Indonesia, Vol. 19, No. 55, pp. 45-48.

Quitadamo, I. J., Faiola, C. L, Johnson, J. E., \& Kurtz, M. J. (2008). Communitybased inquiry improves critical thinking in general education biology. Life Sciences Education, Vol. 7, pp. 327337.
Wahyuni, Sri. (2015). Pengembangan Bahan Ajar IP A untuk Meningkatkan Kemampuan Berpikir Kritis Siswa SMP. Makalah disajikan dalam Seminar Nasional Fisika dan Pendidikan Fisika Ke-6. FKIP Universitas Sebelas Maret. Surakarta, 12 September 2015.

Yuliati, D. I., Yulianti, D. \& Khanafiyah, S. (2011). Pembelajaran Fisika Berbasis Hands On Activities untuk

Menumbuhkan Kemampuan Berpikir Kritis dan Meningkatkan Hasil Belajar Siswa SMP. Jurnal Pendidikan Fisika Indonesia, Vol. 7, pp. 23-27. 